\title{
AN EVALUATION OF NUTRITIONAL AND SENSORY QUALITIES OF WHEAT Moringa CAKE
}

\author{
Kolawole, F.L., Balogun, M. A., Opaleke, D.O. and Amali, H.E. \\ Department of Home Economics and Food Science, University of Ilorin, Ilorin \\ *Corresponding author: e-mail: bmutiatadebanke@yahoo.com
}

\begin{abstract}
The Nutritional and sensory attributes of wheat Moringa cake were evaluated. Cakes were produced from wheat flour and different quantities of Moringa leaf $(2 g, 4 g, 6 g, 8 g$ and $10 \mathrm{~g}$ ) respectively with cake from $100 \%$ wheat flour used as control. Nutritional analyses carried out on the cake samples include crude protein, crude fat, crude fibre, total ash and moisture content. Nutrient contents and sensory attributes of samples were carried out within 24 hours of cake sample production. All parameters determined, showed a significant difference $(p<0.05)$ in cake samples. Moisture (7.35 9.04\%), crude protein (7.21 11.20\%), crude fibre (3.56 5.20\%) and total ash (1.50 2.75\%) showed an increase in value with increase in addition of Moringa while crude fat (5.95 4.00\%) and carbohydrate (74.57 67.82\%) showed a decrease in value with increased addition. Sensory evaluation showed significant difference $(p<0.05)$ between the control $(100 \%$ wheat) and other samples in colour, taste, aroma and general acceptability. The cake sample with $4 g$ Moringa addition was the most preferred in terms of colour, taste, aroma and general acceptability. Cake, being a snack that is commonly consumed by people is made up of high calorie ingredients which when taken for too long may have a negative effect on consumer health. Wheat Moringa cake will have a positive impact of controlling the negative effects of the ingredients used in the production of cake, because of its fibre content.
\end{abstract}

Keywords: Wheat, Moringa, cake, nutritionaland sensory.

\section{INTRODUCTION}

Moringa Oleifera has been described as the most nutritious vegetable plant because of its excellent and enormous benefits. It is entirely edible from leaves to roots; virtually every part of it is edible. The leaves contain significant sources of minerals and vitamins A, B and C. It contains high level of calcium, phosphorus, iron, protein, with low fat and carbonhydrates (Price, 2000; Olushola, 2006). Moringa is a special food for the tropics, because the tree is in full leaf at the end of food scarce (Iwu, 1993). It is available all year round. Fuglie, (2001) describes Moringa as an extremely valuable food source because of its high nutrient profile. 
In the Phillipines where the leaves are cooked and fed to babies, it is called "mother's best friend" or mallungay. Other names include benzolive tree (Haiti), horse raddish tree (Florida) and nebeday (Senegal) (Price, 2000). In Nigeria, it is known as zogale in Hausa, okwe oyiibo in Igbo, ewe ile in Yoruba and jeghel- agede in Tiv (Gernah et al., 2011).

The leaves, seeds and flowers of Moringa oleifera all have great nutritional and therapeutic values. The seeds are eaten like peas or roasted like nuts while the flowers are eaten when cooked and taste like mushrooms (Price, 2000; Olushola, 2006).

Research had shown that ounce for ounce of Moringa leaves contain seven times the vitamin $\mathrm{C}$ found in oranges, four times the vitamin Ain carrots, four times the calcium found in milk, three times the potassium found in banana and two times the protein found in yoghurt. For this reason, it has put Moringa as the most nutritious vegetable plant around and has been used for fortification in noodles, bread, biscuits, porridge and a lot of local, traditional or indigenous foods like gari, yam flour, e.t.c. (Moringa Source LLC, 2012).

It is also known to be the best nutritional support for nursing mothers because, it is not only rich in nutritional content but for its medicinal properties as well. By making vegetable soup out from fresh Moringa leaves, it has been found to increase the volume of breast milk produced by lactating mothers. Moringa is also noted for its anti-bacterial action. French scientists had found that Moringa contains an antibacterial peptide (a molecule composed of two or more amino acids, the building blocks of protein) that can destroy the cell membrane of many infectious bacteria (Arnold, 2007).

Clinical research revealed that Moringa helps prevent mastitis, an inflammation of the breast caused by the blocking of milk ducts while the mother is lactating which a common problem in breast is feeding. This can cause a painful sensation on the breasts or nipples that may lead to fever or flu like symptoms. The most common infecting organism is Staphylococcus aureus that can be found anywhere which can be passed on to the mothers during suckling by their babies. Studies had shown that the antibacterial peptide found in Moringa oleifera is effective against this bacterium (Arnold, 2007).

Generally, snacks including cakes are consumed by different categories of people including the young and old, working class and children of school age. Most snack foods are often considered as "junk food" or empty foods because they contain high levels of calories from sugar or fat with little protein, vitamin and minerals (Oloyede and Kolawole, 2004).

Snacks are important for toddlers and preschoolers because their stomach is smaller and they need to keep their energy level high. It can be difficult for preschoolers to meet all their nutrient needs by eating just the three basic meals which are reasons why snacks are important for preschoolers' diet (American Academy of Pediatrics, 2012). Snack foods are generally preferred by children and teenagers. In these stages of life, the amount and 
nutritional quality of protein are important because of their essential functions in physical and mental development.

Cakes are always readily available and loved by children. The addition of Moringa to cakes will be a vehicle of essential nutrients into the diet of children and teenagers that are the major consumers of cakes.

This research work therefore studied the nutritional or proximate composition of Moringa wheat cakes and evaluates its acceptability through sensory evaluation tests.

\section{Sample Source}

\section{Materials and Methods}

The ingredients used for the baking of the cake were wheat flour (Golden Penny), sugar, butter (simas), eggs, baking powder (River Bridge) which was all purchased from a local market in Ilorin, Kwara State. The Moringapowder was obtained from freshly harvested Moringa leaves, dried at room temperature and ground to a smooth consistency.

\section{Recipe used for Moringa Cake}

The recipe used for the Moringa cake is as follows;

Wheat flour $\quad 300 \mathrm{~g}$

Sugar $24 \mathrm{~g}$

Butter $24 \mathrm{~g}$

Baking powder $\quad 15 \mathrm{~g}$

Moringa leaves powder0g, $2 \mathrm{~g}, 4 \mathrm{~g}, 6 \mathrm{~g}, 8 \mathrm{~g}$ and $10 \mathrm{~g}$

\section{Preparation of Moringa Cake}

Moringa cake samples were prepared following the method of Eke et al., (2008) with some modifications. Three hundred grams of flour were weighed and set aside in a bowl. $24 \mathrm{~g}$ each of sugar and butter were also weighed and mixed to fluffy consistency for 15 minutes using an electric mixing machine. The eggs and baking powder were added to the mixture while the flour was gradually added into the mixture and mixed to form a paste. The paste was divided into 6 portions of $100 \mathrm{~g}, 98 \mathrm{~g}, 96 \mathrm{~g}, 94 \mathrm{~g}, 92 \mathrm{~g}$ and $90 \mathrm{~g}$ with the addition of $0 \mathrm{~g}, 2 \mathrm{~g}, 4 \mathrm{~g}, 6 \mathrm{~g}, 8 \mathrm{~g}$ and $10 \mathrm{~g}$ of Moringa powder to each sample respectively. The control sample $(100 \mathrm{~g})$ had no Moringa powder added to it. The Moringa powder was added to each of the samples and mixed to give a uniform blend.

\section{Baking}

The paste was put into 6 different baking pans which were labeled according to their Moringa content i.e $2 \mathrm{~g}, 4 \mathrm{~g}, 6 \mathrm{~g}, 8 \mathrm{~g}, 10 \mathrm{~g}$ and the control sample. The samples were baked in an electric oven at a temperature of $180^{\circ} \mathrm{C}$ for a period of 30 minutes for the samples that 
contained Moringa powder while the control sample was ready in 15 minutes. The long baking period used in baking the samples containing the Moringa powder was due to the fact that their paste was thicker than the control sample thereby taking a longer time for heat penetration. The baked samples were removed from the oven, depanned and cooled for 2 hours.

\section{Proximate Analysis}

All the chemicals and equipment used for these analyses were obtained from the Chemistry Department, University of Ilorin, Ilorin Kwara State. Moisture content, crude protein, crude fat (ether extract), crude fibre, and total ash were all determined by the method of AOAC, (2000) while carbohydrate was determined by difference (Ihekoronye and Ngoddy, 1985).

\section{Sensory Evaluation of Cake Samples}

Sensory evaluation of the different cake samples was carried out using the 9 point Hedonic scale, by the method of Larmond, (1977). Evaluation was done using 10 panelists who were regular cake consumers. The attributes evaluated were colour, taste, texture, aroma and general acceptability.

\section{Statistical Analysis}

Data obtained were subjected to analysis of variance and means separated by Duncan multiple range tests according to Steel and Torrie, (1981).

\section{Results and Discussion}

\section{Table 2: Nutritional Composition of Wheat- Moringa Cake}

\begin{tabular}{|c|c|c|c|c|c|c|}
\hline Samples & $\begin{array}{l}\text { Moisture } \\
\text { Content } \\
(\%)\end{array}$ & $\begin{array}{l}\text { Crude } \\
\text { Protein } \\
(\%)\end{array}$ & $\begin{array}{l}\text { Crude Fat } \\
(\%)\end{array}$ & $\begin{array}{l}\text { Crude } \\
\text { Fibre (\%) }\end{array}$ & $\begin{array}{l}\text { Total Ash } \\
\text { (\%) }\end{array}$ & $\begin{array}{l}\text { Carbohydrate } \\
(\%)\end{array}$ \\
\hline $\begin{array}{l}\text { Control } \\
(0 \%)\end{array}$ & $7.35^{a}$ & $7.21^{a}$ & $5.95^{e}$ & $3.56^{a}$ & $1.50^{a}$ & $74.57^{\mathrm{e}}$ \\
\hline $2 g(4 \%)$ & $7.61^{b}$ & $8.78^{b}$ & $5.67^{d}$ & $4.10^{b}$ & $2.10^{\mathrm{b}}$ & $72.73^{d}$ \\
\hline $4 g(8 \%)$ & $8.17^{c}$ & $9.84^{c}$ & $5.31^{d}$ & $4.51^{c}$ & $2.50^{c}$ & $69.67^{c}$ \\
\hline $6 g(12 \%)$ & $8.49^{d}$ & $10.70^{d}$ & $5.00^{c}$ & $4.77^{d}$ & $2.61^{c}$ & $68.43^{b}$ \\
\hline $8 g(16 \%)$ & $8.96^{e}$ & $11.01^{\mathrm{e}}$ & $4.50^{b}$ & $5.00^{e}$ & $2.70^{d}$ & $67.83^{a}$ \\
\hline $\begin{array}{l}10 \mathrm{~g} \\
(20 \%)\end{array}$ & $9.04^{\mathrm{e}}$ & $11.20^{f}$ & $4.00^{a}$ & $5.20^{f}$ & $2.75^{d}$ & $67.82^{a}$ \\
\hline
\end{tabular}


Values are means of triplicate determinations on fresh weight basis; means within rows with different superscripts differ significantly $(p<0.05)$

Table 3: Sensory Attributes of Wheat-Moringa Cake

\begin{tabular}{llllll}
\hline Samples & Colour & Taste & Texture & Aroma & $\begin{array}{l}\text { General } \\
\text { Acceptability }\end{array}$ \\
\hline Control (0\%) & $8.6^{\mathrm{d}}$ & $7.9^{\mathrm{d}}$ & $7.5^{\mathrm{d}}$ & $7.8^{\mathrm{e}}$ & $8.1^{\mathrm{e}}$ \\
$2 \mathrm{~g}(4 \%)$ & $7.4^{\mathrm{c}}$ & $6.4^{\mathrm{b}}$ & $6.1^{\mathrm{b}}$ & $6.4^{\mathrm{c}}$ & $6.5^{\mathrm{c}}$ \\
$4 \mathrm{~g}(8 \%)$ & $7.6^{\mathrm{c}}$ & $6.9^{\mathrm{c}}$ & $6.5^{\mathrm{c}}$ & $6.8^{\mathrm{d}}$ & $7.1^{\mathrm{d}}$ \\
$6 \mathrm{~g}(12 \%)$ & $6.5^{\mathrm{b}}$ & $6.3^{\mathrm{b}}$ & $6.1^{\mathrm{b}}$ & $5.9^{\mathrm{b}}$ & $5.8^{\mathrm{b}}$ \\
$8 \mathrm{~g}(16 \%)$ & $6.3^{\mathrm{b}}$ & $6.2^{\mathrm{b}}$ & $6.1^{\mathrm{b}}$ & $6.0^{\mathrm{b}}$ & $5.7^{\mathrm{b}}$ \\
$10 \mathrm{~g}(20 \%)$ & $5.2^{\mathrm{a}}$ & $5.1^{\mathrm{a}}$ & $5.1^{\mathrm{a}}$ & $5.3^{\mathrm{a}}$ & $5.0^{\mathrm{a}}$ \\
\hline
\end{tabular}

Values are means of triplicate determinations on fresh weight basis; means within rows with different superscripts differ significantly $(p<0.05)$.

Results of proximate composition of cakes produced from Moringa and wheat flour blends are given in Table 2. There were significant differences $(p<0.05)$ in the proximate composition of the various blends of Moringa wheat cakes produced in this study when compared to the control. An increase of protein content was observed with increase in the level of Moringa addition. This is expected as Moringa is noted for its high quality and quantity of protein. Cereal grains are limiting in two essential amino acids, lysine and tryptophan. Wheat is not an exception in this; therefore addition of Moringa will be a good complement and therefore producing a better nutritional quality cake. This agrees with previous reports on Moringa and cakes (Olushola, 2006). The higher fibre and ash contents of the Moringa cakes are a justification of the nutritional importance of Moringa oleifera. The utilization of fibre rich plant food is to help in the traffic movement through the intestinal tract (laxative) and in the lowering of cholesterol in blood (American Academy of Pediatrics, 2012) thus help in the control of some prevalent chronic diseases. Also an increase in the intake of dietary fibre supplies greater amounts of vitamins and minerals (American Academy of Pediatrics, 2012). The high ash contents observedare an indication that Moringa is rich in minerals. Moringa oleifera has about 25 times more iron than spinach alone and it enhances recall during tests and exams (Castlerock Farms LLC, 2012). The results of the study also showed a significant decline $(p<0.05)$ in carbohydrate and fat contents. This is in agreement with previous researchers. Foods of low fat are likely to keep longer as they are less prone to rancidity (Balogun and Oyeyiola, 2011). Results of sensory evaluation (Table 3) indicated that all the cake samples were generally acceptable for all the evaluated parameters as none scored below the minimum acceptable rating of 5 on a 9-point hedonic scale. The cake sample from $4 \mathrm{~g}(8 \%)$ Moringa addition was most preferred

\section{Conclusion and Recommendation}

A good quality and nutritious cake can be produced from wheat-Moringa blend. However, at a higher level of Moringa addition, the leafy green taste and colour were highly evident and were not 
highly rated by the panelists though they had higher protein, ash and fibre. At 8\% (4g) Moringa addition, an excellent cake was obtained which was acceptable and loved by all. In conclusion, the research work was able to identify the potentials of Moringa in the productin of cake and this will increase the nutritional status of consumers, especially children and teenagers that are the major consumers of cakes.

\section{REFERENCES}

American Academy of Pediatrics (2012). Fiber: An Important Part of Your Teen's Diet Healthy Children. Retrieved on 26/09/2012 from www.healthy.children.org/English/ages

Arnold, C. (2007). The Potentials of Moringa The Miracle Plant. Retrieved on 04/09/2012 from affleap.com/the-potentials-of-moringa-the-miracle-plant/

Association of Official Analytical Chemists (AOAC, 2000). Official Methods of Analysis (17 Edition). Washington D.C.

Balogun, M. A. and Oyeyiola, G. P. (2011). Microbiological and Chemical Changes During the Production of Okpehe from Prosopis africana Seeds. Journal of Asian Scientific Research 1(8): 390398.

Castlerock Farms LLC (2012). Moringa RX Benefits.Retrieved on 02/09/2012 from www.moringarx.com/benefits/

Eke, J., Achinewhu, S.C. and Sanni, L. (2008). Nutritional and Sensory Qualities of some Nigerian Cakes. Nigerian Food Journal Vol 26 (2), 1217.

Fuglie, L. J. (2001). The Miracle Tree: The Multiple Attributes of Moringa.Church World Service, WestAfrican Regional Office, Dakar, Senegal. Pp 103136.

Gernah, D. I. and Sengev, A. I. (2011).Effects of Processing on Some Chemical Properties of the Leaves of the Drumstick Tree (Moringa oleifera). Nigerian Food Journal Vol 29 (1), 70 77.

Ihekoronye, A. I. and Ngoddy, P. O. (1985).Integrated Food Science and Technology for the Tropics. Macmillan Publishers Ltd., London. Pp 165-172.

Larmond, E. (1977).Laboratory Methods for Sensory Evaluation of Food. Canadian Department of Agriculture Publication, pg 37. 
Moringa Source LLC (2012). Moringa Benefits. Retrieved on 02/09/2012 from www.moringasource.com/products

Oloyede, O. B. and Kolawole, F. T. (2004). Biochemical Assessment of Nutritional Quality of Corn Based Traditional Snacks "Aadun and Masa" Fortified with Soyabeans. Nigerian Journal of Pure \& Applied Science 19: 1602-1609.

Olushola, A. T. E. (2006). "The Miracle Tree", Moringa oleifera (Drumstick). In Achieve Vibrant Health with Nature, Keep Hope Alive Series 1, Unijos Consultancy Limited Press, Jos, Nigeria. Pp 120-136.

Price, L. L. (2000). The Moringa Tree.www.echonet. org.Accessed on 12/08/2012.

Steel, R. G. and Torrie, J. H. (1981). Principles and Procedures of Statistics.A biomedical approach, $2^{\text {nd }}$ ed., McGraw-Hill International, Auckland. Pp 50110. 